\title{
Perpetual Struggle
}

\author{
KATHRYN J. NORLOCK (ID
}

What if it doesn't get better? Against more hopeful and optimistic views that it is not just ideal but possible to put an end to what John Rawls calls "the great evils of human history," I aver that when it comes to evils caused by human beings, the situation is hopeless. We are better off with the heavy knowledge that evils recur than we are with idealizations of progress, perfection, and completeness; an appropriate ethic for living with such heavy knowledge could include resisting evils, improving the lives of victims, and even enjoying ourselves. Better conceptions of the objects of hope, and the good life, inform a praxis-centered, nonideal, feminist ethic, supportive of sustained moral motivation, resilience, and even cheer. I connect elements of stoic and pessimistic philosophy in order to outline some normative recommendations for living with evils. A praxis-centered ethic would helpfully adjust our expectations from changing an uncontrollable future to developing better skills for living in a world that exceeds our control. As Aldo Leopold once said, "That the situation is hopeless should not prevent us from doing our best."

The great evils of human history-unjust war and oppression, religious persecution and the denial of liberty of conscience, starvation and poverty, not to mention genocide and mass murder - follow from political injustice ... Once the gravest forms of political injustice are eliminated ... these great evils will eventually disappear. -John Rawls

I humbly add my own prophecy of what the dawn of the new millennium shall bring forth: one thousand more years of the same, old crap. -Jose Chung

That the situation is hopeless should not prevent us from doing our

best. -Aldo Leopold

Hypatia vol. 34, no. 1 (Winter 2019)

(C) 2018 The Authors. Hypatia published by Wiley Periodicals, Inc. on behalf of Hypatia, Inc.

This is an open access article under the terms of the Creative Commons Attribution License, which permits use, distribution and reproduction in any medium, provided the original work is properly cited. 
The last epigraph above is actually the thesis of this essay. ${ }^{1}$ Against more hopeful and (arguably) optimistic views that it is not just ideal but possible to put an end to what John Rawls calls "the great evils of human history," I aver that when it comes to evils caused by human beings, the situation is hopeless. With the fictional character who voices the second epigraph above, I take it to be evident that the great evils of the past thousand years are well on their way to being instantiated again in this millennium. More, I suggest that establishing all the just institutions one can endeavor to realize will not guarantee future individuals' moral behavior. But arguing for the hopelessness of eliminating evils is not the ultimate point of this essay. The normative implications of the inevitability of evils include working out how each of us might live well, "doing our best" with such heavy knowledge, and continuing to contribute individually to attenuating suffering and ameliorating states of affairs. In what follows, I argue against hopeful progressivism with respect to great evils, and conclude that better conceptions of the objects of hope, and the good life, informed by feminist insights, contribute to an ethic supportive of sustained moral motivation, resilience, and even cheer.

I borrow the phrase "heavy knowledge" from work by Lisa Tessman, who uses it in her essay "Expecting Bad Luck" to describe "knowledge of the predictability of bad luck in one's life" that "warrants pessimism" and potentially consists in a threat to ethics (Tessman 2009, 18). Tessman concludes that although heavy knowledge warrants pessimism, it does not make nihilism inevitable. I conclude similarly that the heavy knowledge any student of evil eventually acquires, that is, the knowledge of the future recurrence of suffering and evil, warrants pessimism but also clarifies appropriate goals, and shifts attention to different sorts of hopes as well as other attitudes. We are better off with the heavy knowledge that evils recur than we are with idealizations of progress, perfection, and completeness, and if we cultivate an appropriate ethic for living with such heavy knowledge, it should not prevent us from doing our best to resist evils, improve the lives of victims, and enjoy ourselves. Instead of hoping for something like Rawls's "realistic utopia," we can cultivate the skills of more resilient knowers in a nonideal world constituted by perpetual struggle (Rawls 1999, 7). I am motivated by my concern for those who enter policy studies and helping professions, in particular, because students of ambitious social change and employees in areas connected to public policy or social service are especially vulnerable to the hopelessness and burnout that can follow the heavy knowledge I describe. ${ }^{2}$ I connect elements of stoic, feminist, and pessimistic philosophies in order to conclude with an outline of some normative recommendations for living with evils.

The skills of resilient knowers will include more than just being prepared for bad news, and will resemble those of stoics, focusing efforts on the cultivation of good practices and more excellent characters, rather than acting for the purpose of achieving outcomes that far exceed our control and would not be enduring even if realized. The attitudes I attend to in my conclusion including a willingness to return to the same task repeatedly, to maintain efforts, and to continually renew commitments. They are forward-looking but not very hopeful, although arguably I rather replace hope in realizing some change goals with hope in realizing adjustment goals. ${ }^{3}$ If this 
Hypatia

forecast of my view sounds Sisyphean, I hope it does not discourage readers from rolling forward anyway. I do not believe I am recommending merely adaptive preferences (what we settle for, versus what we really wish) or being happy at a Sisyphean task. Instead I suggest that we better conceptualize the nature of evils in a nonideal world, or rather, that we cultivate an ethic appropriate to a nonideal world with imperfect humans in it, because it is not clear that an ideal world or perfection of human nature is what we should actually desire. I would go so far as to say that a world in which actual humans thrive and manage to reduce evils will still not be an ideal world. Instead, it will be a thoroughly human world, with unpredictable, nonmechanical, willful beings in it. The sort of "Imperfectionist Ethic" I recommend better equips us to expect individuals now and in the future to get far off track, to exceed our control, to vary and differ. To hope for an ideal world with an absence of evils is to hope for a world that could not contain many imperfect humans. Yet an imperfectionist ethic can be held compatibly with Immanuel Kant's pragmatic answer to the question where our hopes then lie: "In education, and in nothing else" (Kant 1963, 252).

\section{That the Situation Is Hopeless}

Some hope is inevitable in a creature with a will. If one can conceive of a future, and imagine more than one possibility coming to be, then one will unavoidably prefer and come to actively desire some possibilities more than others, and imagine how one can contribute to their realization. Even a good stoic philosopher would live contentedly with some hopes, since stoicism enjoins us to accept that which is out of our control, and many of our hopes are, like David Hume's beliefs, involuntary operations of the mind (Hume 1993). ${ }^{4}$ Indeed, it would be difficult to proceed without them; one wouldn't head to a bus stop if one had no hope of the bus coming eventually. And once there, one hopes the bus arrives before it rains; we cannot help hoping sometimes. ${ }^{5}$

Fighting one's natural capacities for day-to-day hoping would be a foolish expenditure of psychological and philosophical energies, and in this essay I advocate for a stoicism that values living in accord with nature rather than fighting involuntary operations of the mind. ${ }^{6}$ However, not all hopes are involuntary and specific like my hoping a bus will come after I reach the bus stop. We can also cultivate hope as an attitude, informing it with narratives about moral progress, political civilization, the desirability of perfection or personal improvement. When we cultivate attitudes of hope and pursue the reinforcement of cultural or personal narratives so as to build our hopes, then we are responsible for something well within the realm of moral agency, namely, the conduct that we choose and the stories that we endorse in the course of holding hope as an attitude, and building hopes up in a purposeful manner. As Eric Schwitzgebel says, "To have an attitude is, at root, to live a certain way" (Schwitzgebel 2013, 76).

Individual and cultural attitudes toward the eradication of evils are at least partly within each individual's control, insofar as we can critically reflect on prevailing 
narratives, repeat them, and teach them to others. The history of modern philosophy is populated by remarkably hopeful authors endorsing progressive varieties of such attitudes with respect to evils. Before discussing their views, I should clarify that, in discussing evils, I assume a secular stance. It's not just that I take little personal interest in whether or not creator-gods present a problem of evil. It is further the case that I am too ignorant of nonsecular treatments to provide any worthwhile discussion of them. Instead, I shall be operating on Claudia Card's definition of evils, informed by her Atrocity Paradigm, as "foreseeable, intolerable harms produced by culpable wrongdoing" (Card 2002, 3). Evils are the most serious of harms, suffered by victims at the hands of humans who could do otherwise. This is a definition of evils consonant with philosopher Sara Ruddick's, as she, like Card, is preoccupied with practices of violence, for which humans may be culpable whether or not they are intentionally wicked. Ruddick explicitly takes Hannah Arendt's lead in identifying evil by what happens in practice, in human communities, attending to how we go about recognizing evils in the world, rather than attempting to peer into the recesses of human minds; as Ruddick says, "Evil' refers to a relationship ... between evildoers who inflict terrible harm ... and victims who suffer it" (Ruddick 2003, 216). In both Card's and Ruddick's treatments of the concept, evil is a human-caused state of affairs in the world, or an observable set of human-inflicted harms, rather than a mysterious force or a monster in a machine. I shall be discussing evils in this same way, and for the purposes of this paper, I shall be using "evil" and "evils" fairly interchangeably.

Not all harms are evils, and this is important to bear in mind as I proceed to other arguments; Card and I agree that evils are a morally meaningful dividing line. "What distinguishes evils from other wrongs ... are the depth and magnitude of the harm, not necessarily the magnitude of the class of victims"; they are those that "should receive priority over other wrongs," "the wrongs most worthy of attention, most important to avoid perpetrating, and most important to escape, if possible" (Card 2002, 30, 31). My reasons for not holding much hope for the possibility of avoiding such evils are also reasons for finding it interesting and compelling of philosophical attention; the very elements that make harm serious enough to be evil, that is, depth and magnitude of the harms involved, are the same elements that render good outcomes unlikely and motivations to act easily deterred by hopelessness. My attention is rather more focused on living well in the presence of evils, and responding to them as best we can.

Bearing in mind that evils, so conceived, are focused on human-caused harms that are foreseeable and culpable, one may better understand why I say I take a pessimistic approach in my responses to evil. In describing myself as a pessimist, I do not mean that I have negative expectations regardless of the likelihood of positive outcomes, or that I am dedicated to finding the cloud, no matter how small, embedded in every silver lining. I do not have a dour demeanor. If my expectations of bad ends exceeded reasonably good likelihoods, I would describe myself as a cynic, one with such low normative expectations that neither badness surprises, nor goodness relieves me. 
Instead, I intend pessimism to mean rather the negation of what Martin Luther King, Jr. referred to in the course of explaining his optimism. He wrote, to those surprised at his continued hopes in the face of his regular sufferings, jailings, and encounters with wicked oppressors, "It is possible for me to falter, but I am profoundly secure in my knowledge that God loves us; he has not worked out a design for our failure. Man has the capacity to do right as well as wrong, and his history is a path upward, not downward" (King 1986, 314; emphasis mine). The view of humankind's moral and political history as a path upward cannot be set aside as entirely the product of King's Christian faith, especially when it is so consistent with the optimism of nonbelievers like John Stuart Mill. "In every century, progress is made," Mill insists (Mill 1987, 45). "No one ... can doubt that most of the great positive evils of the world are in themselves removable, and will, if human affairs continue to improve, be in the end reduced," and the contingencies of an unpredictable future such as "bad or imperfect social institutions," are "conquerable by human care and effort" (26). Kant sounds a similar note: Progress is interrupted, but never broken off; as Loren Goldman says of Kant's notion of "practical belief," "the hope it characterizes is at once an objectively ethereal and subjectively concrete basis for political action. Even if we cannot accept progress as a fact, we may still need it as a fiction for practical purposes" (Goldman 2012, 499).

Joshua Foa Dienstag notes correctly that such an "optimistic account of the human condition is both linear and progressive"; indeed,

Liberalism, socialism, and pragmatism may all be termed optimistic in the sense that they are all premised on the idea that the application of [human capacities such as] reason ... to human social and political conditions ... will ultimately result in the melioration of these conditions. Pessimism, while retaining a linear account of time and history, denies this premise, or (more cautiously) finds no evidence for it and asks us to philosophize in its absence. (Dienstag 2009, 18)

Dienstag adds that pessimism appreciates the influences of history: "change occurs, human nature and society may be profoundly altered over time, just not permanently for the better" (18).

In other words, and using King's terms, Dienstag and I could say that man's history certainly is a path. We just don't see it as an upward path. I do not see it as a decline, either, and I believe humans can learn from history. Yet whether we do depends on contingencies that perhaps philosophers tend to take for granted, since we tend to be on the comfortable end of their realization; those contingencies include what is taught, and to whom, what technology provides continuing access to that education, and how many have access to that technology, what social and political realities allow access to education, who does the teaching, whether records are kept and memories are retained, and shared. Perhaps some readers have had the experience of finding out about "lost wisdom." That's just the lost wisdom that has been recovered. Wisdom can be lost. 
With respect to evils, there is no reason to believe that the future will be one in which evils cease to be; technology may affect which evils come to pass, but will not guarantee the happiest outcomes of all the contingencies listed above. I have great faith in continual improvements in technology, but it would be erroneous of me to neglect the extent to which humankind has the capacity to use technology for the worse as well as the better. As I have written elsewhere, accurate and negative predictive expectations suggest it is rational to see humans as capable of personal and behavioral change, but outmatched by the seriousness of the problems we face (see Norlock 2010, 38). If one aspires to an ideal world, then one is left with a retreat to "developing adaptive preferences, that is, preferences for what is within the range of options that are available," making a bad situation more livable rather than striving for what one would prefer to prefer (Tessman 2009, 21). This may generate a feeling of despair, a death of hope.

I appreciate Tessman's point that loss of hope, "a disposition to feel persistent hopelessness," contains dangerous potential for oppressed people (Tessman 2005, 37; my emphasis). Her concern about the "psychic and moral damage" of feelings of hopelessness is important, and I do not wish to be taken to recommend suffering from the feelings of loss or despair (37). Nor is mine an argument for giving up desires or for cynicism. On the contrary, I suggest that cynics fall back on assuming a lack of agency when opportunities for agency exist. And a good modern stoic cannot demand the extirpation of desires, to the extent that some are nonvoluntary. So this essay is not a prescription for the death of desires or cynical assumptions. Instead I argue for the value of conjoining pessimism with stoicism as a corrective to despair, and as a corrective to assumptions that underpin hope in upward progress as well as those that underpin extreme cynicism. Stoicism requires working out with accuracy and self-awareness what is in one's control, critically evaluating what is worth aspiration and effort, and what one is prepared to do, rather than attaching oneself to comforting (or for cynics, agency-easing) narratives. It is my contention that ideal theory is one of those comforting narratives.

\section{IDEAL AND Nonideal TheOrY}

I started the essay with the rejection of Rawls's statement, from The Law of Peoples, that "once the gravest forms of political injustice are eliminated by following just (or at least decent) social policies and establishing just (or at least decent) basic institutions," then the "great evils of human history — unjust war and oppression, religious persecution and the denial of liberty of conscience, starvation and poverty, not to mention genocide and mass murder"- these "great evils will eventually disappear" (Rawls 1999, 6-7). Although a confident claim, his is not a probabilistic one; Rawls did not say this was likely. Instead, he was outlining the logically compelling view of justice leading to a "realistic utopia." He emphasized that his realistic utopia, in which evils would cease to exist, was the product of ideal theory; I add that Rawls's was also an optimistic theory. He said, "this scenario is realistic - it could and may 
exist. I say it is utopian and highly desirable because it joins reasonableness and justice with conditions enabling citizens to realize their fundamental interests" (7). He added that further, "we must take note of, even though we cannot properly discuss, the questions arising" - secondarily - "from the highly nonideal conditions of our world with its great injustices and widespread social evils" (89). The nonideal conditions were to be resisted and altered precisely because, as he says, "ideal theory is already on hand," without which nonideal theory "lacks an objective, an aim, by which its queries can be answered"; nonideal theory is, at best, "transitional" (90).

Compare this with Ruddick's response to activist Bernice Reagon saying, "We can choose to be mothers, nurturing and transforming a new space for a new people in a new time":

These words express exactly what I believe and hope. I cannot share Reagon's confidence, however inspired I am by her vision. I see mothering, at its best, as a struggle toward nonviolence, a struggle not to hurt what is strange, not to let [others] be abused out of fear or loyalty to one's own. Yet it is Reagon's vision to which I aspire. After all the caveats and qualifications are in, it is the promising political consequences of maternal identification that underlie my language. (Ruddick 1989, 57)

Now, given her comment about what she believes and hopes, her emphasis on a vision to which she aspires, and the mention of promising consequences, one might conclude, with Rawls, that "ideal theory is already on hand," that Ruddick's nonideal theory is transitional, perhaps not confidently but constructively pursued nonetheless, with Reagon's vision the "objective, an aim, by which its queries can be answered" (Rawls 1999, 90). However, I don't find that Ruddick shares Rawls's view that the ideal ever "could and may exist." Ruddick regularly observed the pervasiveness of suffering and the dimness of the prospects. She sounds a repeated note that evils are inevitable. In Maternal Thinking, she refers to the "ubiquity of war," and suggests, "Anyone might despair of 'peacefulness' amid a violence so pervasive yet often so invisible" (Ruddick 1989, 246, 249). In this early work and in her article, "The Moral Horror of the September Attacks," she repeats at several key points the Simone Weil note that violence has killed, kills, and will kill again, like a sad refrain (Ruddick 2003, 218). Ruddick's writing reveals flashes of pessimism that violence will do anything other than repeat. As she says of World Trade Center victims' narratives, "They express certain values, but they do not console" (218). She seems disconsolate. No hope for a peace politics or feminist resistance is voiced in her essay. No realistic utopia seems possible.

In short, Ruddick appears to be a nonideal theorist and, in addition, a pessimist. She appears to describe evil as inevitable. I'm not just saying she saw individual humans as likely to err, a safe probabilistic claim anyone can make of every individual. What I'm describing is instead a rather more metaphysically accurate view of what it means for humans to be creatures with uncontrolled and sentient wills, rather than the cumulative product of rational lessons from history; this view limits what one can expect as the outcomes of any activism or political negotiation, a world in 
which great evils will not eventually disappear. Note that I am not now drawing out a difference in claims of probability after all; I'm asserting — against Rawls's optimism with respect to bare possibility - that embodied individuals in the material world will continue on all-too-human paths in a way that forestalls those eminently logical possibilities. In other words, rational and just institutions will not necessarily yield rational and compliant actors, because the vision of human actors as rational institution-compliers is already an ideal conception erroneously predicated upon a perfectionist theory that tells a metaphysically mistaken story. My theoretical commitments differ. I hold a view of human nature as capacious and imperfect, rational and irrational, biased and passionate, and multifarious in embodiment and location.

In light of this theoretical commitment, I am moved to doubt that nonideal theory is merely transitional after all. Given the insights of Dienstag with respect to pessimism, perhaps nonideal theory ought to be the theoretical starting point for ethics, and not ideal theory. In other words, pessimism motivates me to prefer nonideal theory, and to proceed from the point of view that, as Charles Mills says, "nonideal theory recognizes that people will typically be cognitively affected by their social location," and theorists like Ruddick and Tessman "map accurately (at least arguably) crucial realities that differentiate the statuses of the human beings within the systems they describe; so while they abstract, they do not idealize" (Mills 2005, 175; emphasis his). (Regarding Rawls's ideal theory in particular, Mills asks, if you were new to academic discourse, "Wouldn't your spontaneous reaction be: How in God's name could anybody think that this is the appropriate way to do ethics?" [169; emphasis his].)

The arguments of Mill, Kant, King, and Rawls are hopeful and even expectant, predicated on an understanding of history and humankind as not just linear, but upward and progressive. We don't just wind social-justice clockwork; we get to watch it run. Generations don't just learn; they keep building on lessons. It is a vision of humans as rational and of history's lessons as cumulative. It relies on plans unfolding, on good institutions yielding compliance, on a sense of direction toward perfectionas Dienstag says, the effects of the accumulation of experience (Dienstag 2009, 32).

Natality complicates the ideal vision. Human individuals are not just the effects of causes; each comes with a will and a variety of capacities. Hannah Arendt draws attention to natality as a source of motivation for action. "The miracle that saves the world, the realm of human affairs, from its normal, 'natural' ruin is ultimately the fact of natality, in which the faculty of action is ontologically rooted .... Only the full experience of this capacity can bestow upon human affairs faith and hope, those two essential characteristics of human existence" (Arendt 1998, 247). Ruddick is one of the only philosophers I've found who indicates that she shares my concern with the negative aspect of natality. She appeals to Arendt's prioritization of natality as a source of motivation, describing the ways in which we attach hopes to new generations, who we can reasonably expect will be capable of learning from the past (whether or not they do), who we can commit to acting in support of in order to promote their learning, flourishing, and even, if only contingently, making that path go a little "upward." But each generation is also a disruption of progress, each new year's children will have to learn from scratch what others took a lifetime to learn, 
and they may not learn it, or they may not do anything about what they learn, or they may turn it to new and unpredictable ends. Her independence from requiring good outcomes of ethical practice is captured by her sentence, "Peacemaking is always specific" (Ruddick 1989, 139). "I grope for images of peace and strategies of peacemaking response to this [violence] — for ways to make manifest in the United States now a maternal resource for peace" (139).

The groping is never done, of course. A "political resister is ... in a position of perpetual struggle,” to borrow Tessman's language (Tessman 2005, 108). Tessman says of the political resister: "She/he displays the traits needed for pursuing an end to oppression, which is, one assumes, what someday could enable - for all — a version of flourishing endorsed by the resister: human lives that are free from domination, exploitation, abuse, war, great deprivation. But these goals are likely to remain unattained, and the resister will be in a position of perpetual struggle, with a constant demand for the virtues of resistance" (205). Tessman specifically discusses anti-oppression activism; I extend her concern for the well-being and persistence of particular oppressed people, who maintain a claim to flourishing that they have no hope of realizing for themselves, to the dispositions of those who aim for the elimination of evils and the enacting of ambitious policies that can realistically be achieved only after their own lifetimes are over, if at all. Social activists are not all oppressed persons (although many victims of oppression are also activists), yet I recognize many activist friends in Tessman's description of "those whose expectation for success (and perhaps also whose hope) is vanishingly small” (Tessman 2009, 13).

One need not even be a pessimist or an optimist, particularly, to appreciate that the potential for evils to be eradicated is low, and if my account is correct, impossible. As Tessman correctly observes, hope is not always warranted when looking squarely at oppressive, systemic harms or evil institutions; "sometimes one can realistically predict that there is essentially no possibility of success," regardless of one's articulate writing, passionate activism, or heartfelt prayers (12). Negative predictive expectations could be paralyzing if one counted on seeing enduring results of one's dreams or efforts. Yet the nonideal pessimist is not free of moral responsibilities even if she is right that her efforts will not be reflected in a better world for very long. The world presents constant demands. One's own body can insist, sometimes against one's inclination, on carrying on. We are called upon to engage in meaningful and moral endeavors, even if we are certain they will eventually fail, or be undone by new challenges and future persons.

\section{Doing Our Best, an Imperfectionist EthiC}

I have argued for a commitment to the imperfectability of humankind in this essay, while maintaining that evils are best responded to with a conjunction of stoic and pessimistic philosophies. Stoicism is usually described as a perfectionist theory, endorsing the quest to perfect one's rational nature. ${ }^{7}$ Given my commitment to a view of humans as importantly imperfect, inevitably irrational as well as rational, and 
noncompliant as well as compliant to social institutions, I will not be occupied with interest in self-perfection. Instead, I am drawn to the wisdom of stoicism for its appreciation of the impermanence of illusory, even undesirable achievements. I have argued that a world in which evils do not recur is a world without many humans in it, and to some this may be desirable. It is not my hope for future generations, but whether one desires a future with fewer humans or fewer evils, our situations are similar on a planet of seven billion people; ${ }^{8}$ we can contribute efforts to constructing just social institutions that bring about our hoped-for futures, and our efforts may be inadequate, or undone, or not sustained after we die. Ayala Pines connects the burnout of social activists to our need to believe our lives are meaningful, that the things we do are useful, important, and even "heroic" (Pines 1994, 381-94). How are we to believe in our agency and in our expectation that future generations will benefit from our efforts, knowing that evils recur?

Stoic philosophers centrally attend to our mortality and to the impermanence of our efforts, and direct our attention to our capacities to cultivate a better character, a more virtuous self in accord with nature. I have argued that it is the nature of humankind to be a species of willful, passionate, and recurrently evil-committing individuals. Knowing this, knowing that resisting and overcoming evils is a temporary success, we could embrace the heavy knowledge and be practitioners of evil-reduction rather than eradicators of future possibility. If all gains are transitory, then we were wrong about the task at hand, or at least, modern progressive thinkers were building the wrong hopes. We would be happier in our efforts if we didn't cultivate attitudes oriented around a fictive endpoint. Repeating and upholding narratives of moral progress may have sold a linear story destined to result in disappointment and burnout. A praxis-centered ethic would helpfully adjust our expectations from changing an uncontrollable future to developing better skills for living in a world that exceeds our control. Note that stoicism does not then allow us to shrug and give up, because we are also constrained to work out what we can do, rather than pretend we are not agents at all. Our agency includes the ability to move one another to help, so collective action is also in our power, or rather, collective practice.

Adjusting our hope-goals to a praxis-conception of responding to evil will not be news to readers who are skilled at maintenance, childcare, housekeeping, nutrition, health services, education, and other practices prioritizing skills and responsiveness to ongoing demands over destinations and rewards. No skilled housekeeper thinks one washing should keep the dishes away forever. No one exercises once and has a permanent hard body. And schools don't close when a class graduates. An imperfectionist ethic accommodates reality and plans on future vulnerabilities and neediness. I suggest that we build different hopes, adjusting to the celebration of priorities that contribute to being an excellent practitioner, such as diligence in rehearsing skills, consistency in repeated reapplication, taking turns, sharing burdens that can't be put down and must, therefore, be traded, and cultivating receptivity to a renewal of promises. Then we could recognize activists, scholars, and policymakers as contributing to something important, useful, and even heroic, as Pines says above. But among the priorities should be better lessons, more accurate cultural narratives to replace the 
stories we currently repeat regarding the moral progress of civilizations, and the individualized versions of those that we cultivate.

One might object that my adjusted goals are merely Sisyphus Fulfilled after all, that I am urging readers to be happy while rolling a stone up a hill that keeps rolling back. ${ }^{9}$ In reply, I clarify my point thus: there is no hill. There is no upward, and no backward, when it comes to good social practice of constructing and maintaining just and responsive institutions. Our attraction to directional metaphors betrays a wishful thinking that moral progress and ambitious policies are achievements with endpoints that we can reach if we just get closer to them with aggressive pushing, wanting it enough, earning the rewards of hard work in the meritocracy of good and evil.

A praxis-centered, imperfectionist ethic does not, I hope I have shown, amount to giving up. Maintenance and recommitment are laborious. I hope I have also shown that I am not describing an exercise in unhappy futility, a stone we can't stop pushing. Practices are not only compatible with enjoyments; they are motivated and sustained by pleasure, too. Pessimism does not prevent one from other goods in life; I can revel in goods including activism, recreation, and affective and loving relationships. The author of my thesis statement, Aldo Leopold, saw environmental deterioration as inexorable, but he greatly enjoyed taking a canoe on singing waters, and celebrated the pleasures of nature, both aesthetic and affective. Indeed, loving the outdoors was his motivational sustenance; he found it "inconceivable ... that an ethical relationship to land can exist without love, respect, and admiration for land, and a high regard for its value" (Leopold 1966, 223). ${ }^{10}$

I find a related argument in Ruddick's work; she emphasizes love and responsive, maternal care. Their approaches to resistance and action are local, specific, and so embedded in relationships and sociopolitical conditions that they need not look up or lay bets. One could do this without hope for greater progress. One could dig in to sites of violence and environmental degradation, and respond to particular evils without expectations that what succeeds in opposition to one historical and philosophical form will succeed against another. Practice-centered conceptions of responsiveness may provide the answer I have long sought to philosopher Margaret Walker's argument that hope is necessary. ${ }^{11}$ At times I cannot find it plausible to think that members of my community and I have shared normative expectations. My hope that rational arguments can persuade political leaders or most of my fellow citizens to acknowledge and respond to evils is sometimes vanishingly small. When hope is all but gone, I require better reasons for action. Nonideal pessimism reminds me of the moral demands of degraded environments and vulnerable people, of the worth of the perpetual struggle. Natality requires us to teach the lessons of history over again, but natality also provides us with sources of joy in educating. I remain pessimistic, but I do not despair.

\section{NOTES}

I am grateful for comments and encouragement from participants in the Nature and Norms of Hope conference at Cornell University, especially Nancy Snow, Lisa Tessman, 
and Margaret Urban Walker, participants in the LaFayette College Environmental Ethics conference, especially Kelly Sorensen, participants in Rice University's Why So Few workshop, especially Sophie Horowitz and Baruch Brody, and participants in the Canadian Society for Women in Philosophy conference, at which Alice MacLachlan was an outstandingly constructive critic. I am especially grateful to Daniel Silvermint and Lisa Tessman for encouraging me to aim to publish this paper when my pessimism outran my stoicism.

1. Sources of the epigraphs are: Rawls 1999, 6-7; Carter and Morgan 1997; Leopold, personal correspondence, quoted in Meine 1988, 478.

2. I am grateful to Daniel Hanneman for bringing the Maslach Burnout Inventory (Maslach and Jackson 1986) to my attention, and for helping me to realize that the problem of burnout for the sustainability of hopes and efforts has been of interest to me for decades.

3. I take the distinction from Susie Sympson and Myra Qualls Elder (Sympson and Elder 2000). I develop this thought in the final section of the article, but note for now that Sympson and Elder describe adjustment-goals in feminist contexts as goals of living well in an oppressive context, whereas change-goals aspire to accomplishing the end of oppression. Although I am anti-oppression, I will not be holding its eradication as a goal in this essay, for reasons that will become clear.

4. I am especially influenced in characterizing Stoicism this way by Epictetus's Handbook (Epictetus 1983); I realize that it is anachronistic of me to include some hopes among the things we cannot control, and that Epictetus did not often excuse hoping, but I cannot help thinking he would be friendly to my accommodating the hopes that are involuntary.

5. It is out of the scope of this essay to consider all the arguments that involuntary, specific, "ordinary uses" of hope are merely metaphorical and not genuine hoping, but I wish at least to provide this note explaining that I reject that conceptual model of hope. The suggestion that hoping is genuine only when the outcome is completely within one's power commits the kind of definitional-stop that theorists often like, providing a tidy account of all hopes as all and only the defensible ones, but that seems to do an injustice to every nontheorist who uses hope to describe "pulling for the bus to come" with perfectly coherent sensibility. Some of it is magical thinking, yes, but it's as earnest as your most well-founded aspiration. I have routinely hoped that the Chicago Cubs would go to the World Series before I die. Some family members have routinely told me that expressing this hope works against the Cubs, because they are hoping that not-saying it is a way to contribute to its realization. (That they have, since my first draft of this essay, won the World Series deeply disturbs my understanding of the nature of the universe, and it is further vexing that now we'll never know which side of the family was hoping correctly.)

6. Living in accordance with nature is common to different accounts of stoicism, although depending on which passages and what texts one reads, this can mean anything from cultivating self-awareness of voluntary agency and involuntary internal processes, to obeying fate and predestination. I am no believer in the latter, and I focus throughout this essay on a sense of living in accord with nature as an effort to appreciate what one can contribute one's agency to, versus what one cannot and should not pretend to control. I 
am specifically appealing to interpretations of stoicism as expressed in Epictetus's Enchiridion; see also Striker 1991; Sellars 2013.

7. On stoicism as a perfectionist theory, see especially Christopher Gill's introduction to Marcus Aurelius: Meditations, Books 1-6 (Gill 2013); other sources include Haybron 2007.

8. If you want to be diverted by the global population count on the world clock, you can find it here: http://www.worldometers.info/world-population/.

9. My consideration of this possible objection is heavily influenced by Susan Wolf's discussion of Sisyphus Fulfilled in her monograph, Meaning in Life and Why It Matters (Wolf 2010, see especially 16-18 and 23-25).

10. I find Leopold's cheerful pessimism and attention to love as a motivation for action fascinating throughout this work. See, for contemporary treatment of this theme, Norlock 2011.

11. See Walker 2006, chapter 2, "Hope's Value."

\section{REFERENCES}

Arendt, Hannah. 1998. The human condition. $2^{\text {nd }}$ ed. Chicago: University of Chicago Press.

Card, Claudia. 2002. The atrocity paradigm: A theory of evil. Oxford: Oxford University Press.

Carter, Chris, and Darin Morgan. 1997. Jose Chung's "doomsday defense” Millennium, season 2, episode 9, directed by Darin Morgan, aired November 21.

Dienstag, Joshua Foa. 2009. Pessimism: Philosophy, ethic, spirit. Princeton: Princeton University Press.

Epictetus. 1983. The handbook (Enchiridion). Trans. Nicholas P. White. Indianapolis, Ind.: Hackett Publishing.

Gill, Christopher. 2013. Marcus Aurelius: Meditations, books 1-6. Trans. Christopher Gill. Oxford: Oxford University Press.

Goldman, Loren. 2012. In defense of blinders: On Kant, political hope, and the need for practical belief. Political Theory 40 (4): 497-523.

Haybron, Dan. 2007. Well-being and virtue. Journal of Ethics and Social Philosophy 2 (2): $1-27$.

Hume, David. 1993. An enquiry concerning human understanding. $2^{\text {nd }}$ ed., ed. Eric Steinberg. Indianapolis, Ind:: Hackett Publishing Company.

Kant, Immanuel. 1963. Lectures on ethics. Trans. L. Infield. New York: Harper \& Row.

King, Jr., Martin Luther. 1986. A testament of hope. In A testament of hope: The essential writings and speeches of Martin Luther King, Jr., ed. James M. Washington. New York: Harper \& Row.

Leopold, Aldo. 1966. A Sand County almanac, with essays from Round River. New York: Ballantine Books.

Maslach, C., and S. E. Jackson. 1986. Maslach burnout inventory manual. $2^{\text {nd }}$ ed. Palo Alto, Calif.: Consulting Psychologists Press. 
Meine, Curt. 1988. Aldo Leopold: His life and work. Madison: University of Wisconsin Press.

Mill, John Stuart. 1987. Utilitarianism. Buffalo, N.Y.: Prometheus Books.

Mills, Charles W. 2005. "Ideal theory" as ideology. Hypatia 20 (3): 165-84.

Norlock, Kathryn J. 2010. Forgivingness, pessimism, and environmental citizenship. Journal of Agricultural and Environmental Ethics 23 (1-2): 29-42.

- 2011. Building receptivity: Leopold's land ethic and critical feminist interpretation. Journal for the Study of Religion, Nature, and Culture 5 (4): 491-509.

Pines, Ayala M. 1994. Burnout: An existential perspective. Journal of Health and Human Resources Administration 16 (4): 381-94.

Rawls, John. 1999. The law of peoples. Cambridge, Mass.: Harvard University Press.

Ruddick, Sara. 1989. Maternal thinking: Toward a politics of peace. Boston: Beacon Press.

—. 2003. The moral horror of the September attacks. Hypatia 18 (1): 212-22.

Schwitzgebel, Eric. 2013. A dispositional approach to attitudes: Thinking outside of the belief box. In New essays on belief: Constitution, content and structure. London: Palgrave-MacMillan.

Sellars, John. 2013. The art of living: The Stoics on the nature and function of philosophy. London: Bloomsbury Publishing.

Striker, Gisela. 1991. Following nature: A study in Stoic ethics. Oxford Studies in Ancient Philosophy 9 (1991): 1-73.

Sympson, Susie, and Myra Qualls Elder. 2000. Feminist therapy as empowering hope. In Handbook of hope: Theory, measures, and applications, ed. C. R. Snyder. San Diego, Calif.: Academic Press.

Tessman, Lisa. 2005. Burdened virtues: Virtue ethics for liberatory struggles. Oxford: Oxford University Press.

- 2009. Expecting bad luck. Hypatia 24 (1): 9-28.

Walker, Margaret Urban. 2006. Moral repair: Reconstructing moral relations after wrongdoing. Cambridge, UK: Cambridge University Press.

Wolf, Susan. 2010. Meaning in life and why it matters. Princeton: Princeton University Press. 